\title{
Value and Impact of Adult Education: Voices of Zambian Communities
}

-Daniel L. Mpolomoka: School of Education, Department of Adult Education Zambian Open University, Lusaka, Zambia.

Musonda Luchembe: School of Education, Department of Adult Education and Extension Studies, University of Zambia, Lusaka, Zambia.

Selina Banda: School of Education, Department of Adult Education Zambian Open University, Lusaka, Zambia.

Peter Sampa: School of Education, Department of Adult Education and Extension Studies, University of Zambia, Lusaka, Zambia.

ABSTRACT: Zambian communities are rich with voices of the value of adult education, albeit unsystematically documented. It is these insightful voices that this article unveils. Phenomenological research design was employed. Three research sites were targeted comprising two chiefdoms and covering four villages, two villages from each chief dom. Data was collected using interviews and focus group discussions. After coding the data, narrative and thematic methods of data analysis were used. Findings reveal that the value of adult education is measured informally by the number of the adult population able to access social amenities equitably and equally on one hand, and on the other, by their ability to read the ,word and the world" as purported by Freire and Macedo (1987).

Key words: Value, Adult education, Community.

\section{Introduction}

The development of adult education is very vital because every society which is committed to achieve community and economic development and social transformation should have educated citizen who can participate willingly, intelligently and efficiently in all developmental programmes of the country. This article presents an analytical phenomenological reflection on the role and impact of adult education in two chiefdoms in two villages in Zambian local communities.

International Journal of Educational Studies

Vol. 2, No.4, pp. 287-292

2019

DOI: $10.53935 / 2641-533 x . v 2 i 4.131$

* Corresponding Author: Daniel L. Mpolomoka Funding: This study received no specific

financial support.

Received: 17 September 2019

Revised: 14 October 2019

Revised: 14 October 2019

Accepted: 26 November 2019

(C) 2019 by the authors licensee Academic

Publishing Group

\section{Objective}

The main objective of this article was to explore the value and impact of adult education in local communities in two chiefdoms, particularly two villages in each one of the two chiefdoms.

The education of adults is a multifaceted complex process, which includes many subject and interest areas. It is broad and varied as those it serves. It encompasses Adult Basic Education (teaching basic learning and survival skills to the undereducated), continuing education efforts for personal and professional growth, and enrichment activities for the highly educated. It is designed for personal skill development, for enhanced career opportunities, or for enjoyment. It can involve a very short duration of 
time or several years of effort. Finally, it serves a diverse group of participants and includes a varied population of adult teachers.

\section{Methodology}

Phenomenological research design was employed. According to Christensen, Johnson, and Turner (2010) the primary objective of a phenomenological study is to explicate the meaning, structure, and essence of the lived experiences of a person, or a group of people, around a specific phenomenon. Three research sites were targeted comprising two chiefdoms and covering four villages, two villages from each chiefdom. Data was collected using interviews and focus group discussions. After coding the data, narrative and thematic methods of data analysis were used. This is in line with the assertion by Simon (2011) that although the most common means of data collection in a phenomenological study is through in-depth interviews to gather the participants" detailed descriptions of their experience, participants" written or oral self-reports, or even their aesthetic expressions (e.g. art, narratives, or poetry) can also be evaluated.

\section{Findings and Discussion}

The findings are presented through the lens of the main objective of the article. Predominantly narratives and themes formed the basis of analysis of the findings presented herein. These are covered in the subthemes categorised below.

\subsection{Theme 1: Valuing Adult Education in Zambia}

In Zambia, value of adult education is seen in its role in enabling participants to acquire required knowledge and skill for their proper functioning in their lives. This is because adult education fosters peoplees realization of their abilities to improve their lives. In his article, how adult education can save your life, Lopes (2018) contends that it is time to place preventive healthcare education in the same category as literacy and numeracy, and re-evaluate the importance of lifelong learning for our survival. Indeed, adult education is a type of education provision that caters across life spun by offering knowledge and skills according to people $\mathrm{s}$ specific needs. Adult education offers some, who were not privileged, a last chance to learn. Some feel a need for training in basic skills of learning so they can enrol for learning, reading, writing and arithmetic.

The functional and organizational diversity of adult education is evident in various professions and occupations. Beginning with people with little or no literacy skills up to those who already have but need to continue learning, adult education fits in well. The value of adult education cannot be under estimated. Those working in the field include the administrators, researchers and professors in university graduate programs that train adult educators and maintain adult education as an academic discipline. Teachers and student-service personnel in university, governmental, and proprietary organizations deliver graduate, undergraduate, and continuing education to adults. Managers, trainers, and associated marketing and support personnel staff the employee, technical, and professional training industry.

Adult education equips learners in a community and the nation as a whole with skills through formal and non- formal education. In Zambia, many people have benefitted from its provision. There are many types of adult education programmes offered in various parts of the country. Government and nongovernmental organisations provide adult education programmes. Notably, public trade institutes scattered around the country are known for their contribution to offering craft skills in many study areas. Tailoring, mechanics, building, electrical, business, computer studies and many others, are examples of courses offered at these public institutions. Non-governmental organisations also provide adult education programmes, or instance, vocational training centres in Kabwata like „Mulele Mwana", provides learners with skills which include; carpentry, bricklaying, tailoring, auto mechanic and power electrical courses.

\subsection{Theme 2: Measuring Impact of Adult Education in Selected Zambian Local Communities}

It is not always easy to measure the impact of an activity or programme in the humanitarian sector. We devised a way of measuring the impact of adult education on communities by getting their perceived 
benefits and harms on their lives. We made reference to people $\mathrm{s}$ voices which depicted their experiences as regards adult education. We therefore looked at various adult education programmes provided in selected communities to note how their impact was felt. This way of obtaining quality narrative information from participants is often used by researchers. For example, in a study by Lopes (2011) it was established that women made their won self-evaluations in relation to a set of indicators covering the three interrelated concepts before and after participating in adult education.

\subsubsection{Sub Theme 1: Agricultural Extension Services}

Agricultural extension services offered to farmers include aspects of education. Farmers are trained on farming methods in growing crops and rearing animals. Through Ministry of Agriculture, workshops are organised necessitated by the need to empower farmers with knowledge and skills in improving food production. Nutrition is another aspect which is taught to farmers so that they are directed on producing nutritious food. The ministry always emphasizes the need for crop diversification as a way of improving crop production which can sustain people ${ }^{e e}$ nutritional status. Efforts to enable farmers diversify their food production are being made through organizing non- formal education. Notably, Ministry of Agriculture, used Programme Against Malnutrition (PAM) to educate farmers on the need to produce crops that provided a balanced diet (Banda, 2011). Some farmers were first enlightened on crop diversification before giving them farming inputs to achieve production of required crops.

While some farmers have continued to grow a variety of crops even after PAM pulled out, others have gone back to their old ways of concentrating on growing the main crop which is maize. Maize is a good source of carbohydrate which is regarded as a traditional crop. One of the beneficiaries of PAM"s initiative explain why she stopped crop diversification. I don"t grow any other crops apart from maize anymore because my piece of land is too small to accommodate these other types. When she was given seeds for other types of crops, she managed to grow them. However, when she stopped receiving farming inputs from PAM were not forth coming, crop diversification was stopped.

On the contrary, other farmers have continued with crop diversification according to PAM"s plan. These are farmers who grow maize, groundnuts and beans. They have enriched their diets with crops that provide them with proteins and fats. This means that nutrition education which was offered to some farmers was not used to enrich their diets. Nutrition education had a negative impact on some farmers. However, other farmers are using nutritional knowledge to grow crops that can provide them with required nutrients. Impact of non-formal education in the agricultural sector can be measured by farmer"s continued adherence to knowledge and skills offered. What is interesting is that the Background Document prepared for the $8^{\text {th }}$ CCNGO Global Conference in Sien Reap this past May (2017), civil society organisations (CSOs) "considered that lifelong learning continues to be neglected, with adult education, adult literacy (including new forms of literacy) and non-formal education occupying a weak place in the agenda".

\subsubsection{Sub Theme 2: Craft Training}

Non-formal education offers training to adults who want to acquire craft skills. Common courses offered include carpentry, bricklaying, welding, plumbing, mechanics, electrical and tailoring. Most of these craft courses are offered in trade schools where adults go to learn. The majority of the people who these courses attain skills which they use to earn a living. Some of the people who attained these skills are self-employed. For example, plumbers and bricklayers look for jobs to build houses and fix plumbing fittings. One of the community members who attained craft skills in plumbing attests to the benefits he accrued from a craft centre in Kabwe District.

I got these plumbing skills from the craft centre, although I did not finish the course due to financial constraints in paying fees, I attained enough plumbing skills to apply and earn some money.

Vol. 2, No.4, pp. 287-292

2019

DOI: $10.53935 / 2641-533 x . v 2 i 4.131$ Corresponding Author: Daniel L. Mpolomoka Funding: This study received no specific financial support.

Received: 17 September 2019

Received: 14 October 2019

Revised: 14 October 2019

Accepted: 26 November 2019

(c) 2019 by the authors; licensee Academic

Publishing Group

One man who attained bricklaying skills from the trades centre uses them to earn a living. He explained that: I know how to build houses. There are many people who contract me to build their houses. Because I cannot work alone, I engage other people who work under my instructions to mix cement and sand after I measure the correct quantity. You know some of these people who work under me, have gained some skill and are doing well. This is an indication of transference of skills from those 
who have to others bereft of them. Some skills acquired in adult education are not only practical in nature, but have a trickle-down effect. Some young men attested to this fact that:

We learnt how to build by following instructions which our "boss" gave us.

We can now work under minimal instructions from him. All that is needed is

paying attention to given instructions and when they are repeated several time, it becomes easy to work.

The other one is Young Women Christian Association which offers catering courses in the same area. Because some of the courses offered do not require school certificates, they cater for those who did not finish high school or did not get good grades to enter other institutions of learning. For example, a woman who participated in a course at a trades institute attested to the benefits which she accrued from the craft course. ,I learnt how to cut and sew at the trades centre for one year and now I have my own sewing machine which I use to sew people dresses". Hence, these skills make the Kabwata citizens selfreliant as they are able to afford to provide for their families.

On the other hand, others get employed in some industries. Similarly, those that are skilful in tailoring design garments for other people. These many other courses offered under non-formal education demonstrate some positive impact on the livelihoods of the people. Looking at the way some of these adults who attain knowledge and skills, it clear that non-formal education contributes to improving people ${ }^{e s}$ livelihoods. Of course, there are a few who do not to utilize the skills they attain from craft centres.

Generally, non-formal education provision in craft training has had a positive effect. The effect can be measured by the changes in peoplees livelihoods upon attaining required skills.

\subsubsection{Sub Theme 3: Functional Literacy}

Even though it has taken so long a time since Zambia undertook a national-wide literacy campaign (1996), isolated and uncoordinated efforts towards literacy education have been recorded, albeit unsystematically... Functional literacy has been advocated for in various policy documents including the National Development Plans and Education Policy Documents. This has given impetus to government ministries (Ministry of Education, Ministry of Health) and Non-Governmental Organisations to combine efforts in advocating for functional literacy among the adult population. For example, so as to reposition itself, government moved the responsibility of offering adult education, from the Ministry of Community Development and Social Services to the Ministry of Education. In addition, NGOs like Peoplee s Action Forum (PAF), an international organization which teaches illiterate people how to read and write around the country (Peopleees Action Forum, 2017). One of the participants in an adult literacy class in Chipata District explained how she has benefitted from the provision of inherit skills:
"It was too embarrassing and shameful whenever one of my children asked me to help them with their home- work. I would quickly come up with an excuse. Little did they know that I was unable to read or write" says one of the PAF literacy beneficiaries in Eastern Province in Chipata. "Now I am able to write my own name and calculate", explains a mother of six, Eunice Zulu of Kagunda village in Chipata.

\subsubsection{Sub Theme 4: Community Health and Nutrition Education}

Community health education programmes in Zambia are carried out by the Ministry of Health through hospitals, rural health centres, faith-based organizations, non-governmental organizations and many other organizations. They do that through their adult educators. Topics of discussion vary from the benefits of circumcision, breastfeeding, HIV and AIDS, cholera, and many more. Often times, the goal of government and all those that are involved is to increase the quality, availability, and effectiveness of educational and community-based programmes designed to prevent disease and injury, improve health, and enhance quality of life.

Adults are offered nutrition education at health centres such as hospitals and clinics. There are special sessions held in which nutrition and health issues are addressed. Pregnant mothers are educated on how to use food properly to achieve a balanced diet required for them to keep health. Mothers are further educated on how to provide healthy food to their children when they go to under-five clinic

Studies

Vol. 2, No.4, pp. 287-292

2019

$35 / 2641-533 x . v 2 i 4.131$

Conding This Author: Daniel L. Mpl Funding: This study received no specific Article History:

Received: 17 September 2019

Accepted: 26 November 2019

Published: 19 December 2019

(C) 2019 by the authors; licensee Academic

Publishing Group

$$
\text { | } 290
$$


sessions. Some mothers attend nutrition sessions in their communities which are organised by some nongovernmental organizations.

Notably, in Ndola, there are community based nutrition education projects dotted in several communities which supplement government"s efforts in teaching mothers appropriate dietary practices for their children. Some communities have nutrition clubs where members share knowledge and skills in food preparation. People who attend these sessions on nutrition have demonstrated some positive changes in the way they prepare their meals. One of the member explained how she able to prepare nutritious porridge for her baby. One of the club member demonstrated to us how to add kapenta (a type of small fish) to porridge. I cook porridge using pounded mealie meal and kapenta. My baby eats. These mother always consider including nutritious types of food in their meals.

There are some adults who have developed adverse health conditions such as hypertension and diabetes who have been educated on how to maintain their health by avoiding certain types of food or eat them in moderation. Some of these people have changed their dietary practices due to the nutrition education they received. Non-formal education in nutrition has made a positive effect on dietary practices of some people. One of the men who developed diabetes attended a training sessions offered at the University Teaching Hospital explained how he has changed his dietary practices by avoiding too much carbohydrate food sources. He values the training he received because it has enabled him to manage his diet. He confirmed thus: I attended those training sessions for people who have „sugar disease". In a group, we were taught how to eat suitable food and taking care of our bodies. In my condition, I am supposed to exercise physically on a regular basis. I try to follow the tips given and I do not feel as tired as I used to before I changed my life style. According to Latchem (2014) non-formal education conducted in this way is meant for self-development. It has enabled some people to develop attitudes towards nutrition which promote their wellbeing. Adult education is key in enabling people improve their health status (Belgutay, 2017).

Similarly, nutrition education meant for adults has had a positive impact on the lives of some adults in Northern Province, in particular, Luwingu, Mporokoso, Mbala districts. Self-Help Africa (SHA), an international organization, funded by the Ireland government, works to improve lives in Africa. It is involved in agriculture to imbue a focus on nutrition by demonstrating cookery lessons as well as teach sanitation and hygiene. Since 2013, SHA has consolidated local stakeholders" ties with various government structures in most parts of Northern Province.

\subsubsection{Sub Theme 5: Morality in Adult Learning}

Some traditional communities practise polygamy. It is morally right for men to marry more than one wife. It is not regarded as a moral problem to engage in illegal friendship with women that are married close to relations. Adult education has influenced some community members to develop more acceptable spiritual and moral behaviour than before. For instance, religious institutions initiate their own education through the support of community facilities either through the church or the mosque. This has resulted into seeing young men and women change their traditional spiritual beliefs and engage in modern religious faith and practices. Today, may community members have adopted these moral standards and are involved in domesticating them for the benefits of their families, communities and nation at large.

\subsubsection{Sub Theme 6: Civic Education}

Another way through which adult education is used in communities, is to teach people about their civic rights and duties. The Electoral Commission of Zambia and some non-governmental organisations have used adult education to teach people about their rights to vote and their civic duty to demand for what is rightly theirs. Civic education has improved people's perceptions of their rights. They are no longer easily manipulated by community leaders. One woman explained that: "I know my rights and no one can force me to choose a leader I do not want". The other man said that: "I am ,politically mature" because I was taught how to exercise my rights".

Increasingly true, members of various communities have now learnt how to demand for their right from government; and communicate directly with the government for provision of basic needs. Educated adult members of various communities are interested in demanding from the government either through individuals or delegation of members to government officials for provision of electricity, water, good 
roads, security, markets, housing, communication equipment, higher education, agricultural technologies among others as their right from government. UNESCO (2017) asserts that "the principle of nondiscrimination means that education must be available to people of all ages, throughout life".

Similarly, the increase in adult education provision in communities makes some of these practices now give way to better understanding of relationships with other communities and benefits that should accrue to them from the government to which they belong. In fact, with education, members are more competitive in development, they are more jealous about what other communities possessed but they are denied.

\section{Way Forward}

Adult education activities must be entrusted in capable hands. This implies that those people qualified enough must be given chance to handle matters related to adult education. Moving forward, there is need for the Ministry of Education, Directorate of Open and Distance Education, which is dully mandated to coordinate adult education activities and programmes to scrutinise officers appointed to the Directorate so as to ensure that they have adult education qualifications. This will make the Directorate tick and meaningfully advance adult education activities and programmes.

Adult education practitioners must make their role known so that the field of study can be recognized. Doing so, will contribute to organizing context-specific adult education programmes meant to benefit a diverse population. For example, a national-wide campaign to advocate for and educate the masses on adult education as a field of study, can be organized. Once awareness in adult education is made, people will begin to appreciate its value. This will tone down the current misconception of „Adult Education".

\section{Conclusion}

Benefits of non-formal adult education are difficult to measure. This is because knowledge and skills accrued from programmes are usually for personal gain. People attend adult education so that they acquire skills which they need to perform required tasks. This paper has documented adult education provisions which are socially recognized. What some people have demonstrated due to attaining skills attests to the value that non-formal education, a component of adult education, has contributed to various communities. Social recognition refers to knowledge and skills which those who have attended nonformal education demonstrate to perform required tasks in communities, (Outcomes, Policies, \& Practices, 2010). Voices from communities on accrued benefits have been used to depict how adult education is impacting on people's livelihoods. We have used perceived benefits from people's participation in adult education programmes to show how it has positively improved their livelihoods.

\section{References}

Banda, S. (2011). Functional literacy: Impact on nutrition for illiterates: Lambert Academic Publishing.

Belgutay, J. (2017). What is the true value of adult education?

Christensen, L. B., Johnson, R. B., \& Turner, L. A. (2010). Research methods, design, and analysis (11th ed.). Boston, MA: Allyn and Bacon.

Freire, P., \& Macedo, D. (1987). Literacy: Reading the word and the world. South Hadley, MA: Bergin \& Garvey.

Latchem, C. (2014). Informal Learning and Non-Formal Education for Development. Journal of Learning for Development, 1(1), $\mathrm{n}$.

Lopes, H. (2018). How adult education can save your life. Role and Impact of Adult Education, Bonn(85), 18-20.

Lopes, H. (2011). Family, a key variable to explain participation in NOI and lifelong learning. In: Accreditation of prior learning as a lever of lifelong learning (pp. 263-318). Brussels: UNESCO/UIL and Menon Foundation.

International Journal of Educational

Studies

Vol. 2, No.4, pp. 287-292

2019

DOI: $10.53935 / 2641-533 x . v 2 i 4.131$

Corresponding Author: Daniel L. Mpolomoka Funding: This study received no specific financial support.

Article History:

Received: 17 September 2019

Revised: 14 October 2019

Revised: 14 October 2019

Accepted: 26 November 2019

(D) 2019 by the authors; licensee Academic

Publishing Group Retrieved from http://www.oecd.org/education/innovation-education/45007044.pdf.
Retricies, \& Practices. (2010). Recognition of non-formal and informal learnin

People se Action Forum. (2017). 21 years with adult education at the core of our development agenda. Retrieved from http://paf.org.zm/?v=70f73ee5133f.

Simon. (2011). Dissertation and scholarly research: Recipes for success. Seattle, WA: Dissertation Success LLC.

UNESCO. (2017). CCNGO 8th meeting background document. Retrieved from http://bit.ly/2p3og88. 